\title{
The Portrayal of Working Class People in African Novels: A Study of Festus Iyayi's Violence
}

\author{
Abubakar Mohammed Sani \\ Faculty of Modern Languages and Communication \\ Universiti Putra Malaysia \\ E-mail: abusanimoh@yahoo.com \\ Manimangai Mani \\ Faculty of Modern Languages and Communication, \\ Universiti Putra Malaysia
}

Doi:10.7575/aiac.alls.v.5n.4p.38

Received: 11/04/2014

URL: http://dx.doi.org/10.7575/aiac.alls.v.5n.4p.38

Accepted: 14/06/2014

\begin{abstract}
This essay investigates the depiction of the condition of working class people in African novels with particular reference to Violence by Festus Iyayi. The paper examines, first of all, the concept of violence from a Marxist perspective of Franzt Fanon. Furthermore, the paper relates the view of Fanon on violence to what is depicted in the primary text of the paper. The paper argues that the portrayal of the working people in the novel by Iyayi tallies with the view of Fanon in his definition of the concept of violence. The paper exposes how the working people class are presented in the novel as those people who are always in the process of asserting their existence through struggling for survival by selling their labour to the capitalists in order to earn a living. The paper blames this act of suffering on colonialism and neo-colonialism imposed on the African people.
\end{abstract}

Keywords: Working Class People, African Novels, Festus Iyayi’s Violence

\section{Introduction}

This paper aims at examining the portrayal of working class people in Violence by Festus Iyayi of Nigeria. The concept of violence according to Franzt Fanon's definition of violence are multifaceted. These are physical harm and mental harm. The former was of course, the vital backbone of the colonialism. It was important to make colonized colonies submit to the imperialist economic desires of the colonizing capitalist. In fact, the antagonistic relation between colonized and colonizer makes all colonial societies move towards the police state. On the other hand, in a neo-colonial situation, the presence of physical violence is evidently attenuated and diffused. Despite the diffusion, it continues as the vital instrument of the local comprador - bourgeoisie in its collaboration with the foreign capitalist in exploiting more surplus value from African working class.

In other words, mental violence in both the colonial and the neo-colonial cannot be divorced from physical violence.

Religion and sexuality, for instance are parts of the super structure fashioned by the neo-colonial ruling class as effective weapons to exert mental violence on African working class. Some class values enshrined in religion and sexual relations serve to sustain the exploitative social relations of production.

However, sexuality occupies a crucial position in Fanon's theory of mental violence. In colonial and neo-colonial societies, patriarchal values predominate, and women are the victims of these values, suffering from sexual discrimination and exploitation, particularly when they are working class women. Their social condition is worst when they live in feudal societies that have undergone foreign domination. As a result Fanon posits that post-colonial revolutionary African;
...must guard against the danger of perpetrating the feudal tradition which holds sacred the superiority of the masculine element over the feminine. Women will have exactly the same place as men, not in the clauses of the constitution but in the life of everyday. (Fanon, 1977: 163).

The use of violence by the exploiting and ruling social classes calls forth the redeeming violence of the 'damned'. Dialectically, Fanon justifies the use of violence as an instrument of liberation, because the only language the colonialist understands is the use of force. In other words, the violence of liberation is never violence for violence's sake, but a physically and spiritually redeeming counter-violence. To some critics, violence must be broadly conceived as meaning economic, political and ideological as well as military struggle between the 'dammed' and the exploiter. 
In liberating themselves by counter - violence from all kinds of alienating mental and physical violence imposed by the colonial and neo-colonial exploiters, the working class would also be working towards the dis-alienation of the exploiters,_(Fanon, 1971: 228).

The portrayal of African working class in Violence is workers are the producers of all social wealth, as it is globally. For instance, in Violence, the working class are represented by Idemudia and others who gather at Iyaso Motor Park constantly searching for work to do to survive and fend for their families. People are forced to sell their labour power to the local bourgeoisie in order to survive. They are employed, mostly on daily basis, so there is no job security. Since the surplus-value created is to be shared between the local and the foreign masters. Idemudia and his colleagues are grossly exploited as manual labourers in off-loading cement bags and as workers with building contractors.

For more than four hours, the four men laboured to clear the cement. Osaro and Patrick stayed on top of the trailer from where they handle down the bags of cement to Idemudia and Omoifo who then carried them either on their heads or on their backs to the shed, more than ten metres away. At the beginning they shouted as they worked... But gradually, their shouting died out. They became silent as they worked into the evening and as the hours passed, they became worn out. (Iyayi, 1979: 34).

A clear depiction of patriarchal and sexist values is to be found in the novel. The comprador bourgeoisie uses women to gain contracts. It should be noted that the 'proletarian' revulsion manifest by Idemudia and Adisa when they are asked in different occasions, to satisfy the sexual needs of members of the comprador class. For example Adisa, the wife of Idemudia, unintentionally submits herself to sexual humiliation in order to get money to settle her husband's hospital bill.

Thus, the working class people have to undertake often inhuman tasks to regain crumbs of surplus values which they themselves created. Idemudia and comrades even have to sell some pints of their blood in order to survive (P. 253).

The social situation of the twentieth century neo-colony is strikingly shown in Violence. Obofun, a highly placed bourgeoisie civil servant, and his wife, Queen, squander a great deal of cash on expensive cars. They certainly do not present the image of the thrifty and hard working bourgeoisie which is interested in saving capital in order to move from the position of hoteliers and renters or landlords to that of manufacturers and industrialists.

Moreover, the organized violence of the state is depicted in the novel. Idemudia and his co-workers are threatened with state violence if they press on with their case for an increase in their daily wages.

Queen, the business woman, feels very comfortable in her handling of the workers' demand because of her personal connections with some highly placed civil servants, who guarantee police protection if ever a protest should arise.

Iyayi in Violence portrays the working class not as passive but as individuals who believe in struggling for their freedom, who are conscious and are prepared to face their problems courageously. Similarly, they are presented not as faultless heroes but also have their human weaknesses. For example, Idemudia is tempted to propose to Queen even though he realizes that this might seriously affect the ongoing struggle between Queen, the contractor and Idemudia's own labour union.

In the novel, Festus Iyayi, presents a balanced picture of both the working class and of their exploiters. Both social class are infallible. They both show a degree of human weaknesses and strength, although it is abundantly clear that the author is on the side of the working class.

As a radical writer, he is not complacent towards the plight of those who have only their labour to sell. But he does not legitimize Idemudia's attempt at beating his wife; neither does he approve of the sexual methods of Adisa, who searches for money to pay off Idemudia's hospital bill, when he was hospitalized and has no money to settle the hospital bills. Emphasis is given to the creative role of labour in Iyayi's work. Working class are essentially responsible for humanizing the natural surroundings of mankind:

Not far off were the houses which sweat and labour had already erected. Life there was ablaze where labour had left its positive mark, the Sunlight or in the biting cold or in the blinding rain, piling the blocks higher and higher and wiping the salt and the sweat from their eyes and their foreheads with the backs of their hands and all under paid, treated no better than slaves. (P. 247).

The people in Violence are presented as indispensable agents of human progress.

The novel vividly rejects the presentation of a situation in which '...slave traders took all the credit for the achievements of the slaves' (P. 247). Iyayi rehabilitates the image of working class as the primary historical force, and are to be politically reckoned with in society. This views on the working class reminds one of Bertolt Brecht's poem: 'Questions From a Worker Who Reads' (1976: 252). The poem reads as: 
Who built Thebes of the seven gates?

The history books give the names of kings.

Did the kings haul up the lumps of rock?

And Babylon, many times demolished

Who raised it up so many times? In what houses

Of gold-glittering did the builder live?

Where, the evening of the wall of China finished. Did the Mansons go? Great Rome

Is full of triumphal arches. Who erected them?

Over whom

Did the Caesars triumph? Had Byzantium, much praised in song

Only palaces for its inhabitants? Even fabled Atlantis

The night of the Ocean engulfed it

The drowning still bawled for their slaves.

The young Alexander-conquered India

Was he alone?

Caesar beat the Gauls.

Did he not have even a cook with him?

Philip of Spain wept when his armada

Went down. Was he the only one to weep?

Fredrick the second won the Seven Years' war,who

Else won it?

Every page a victory.

Who cooked the feast for the victors?

Every ten years a great man.

Who paid the bill?

So many reports.

So many questions. (Brecht, 1976: 25).

However, in a colonial and neo-colonial situation one cannot but give credence to a Fanonist view of violence. This school of thought regards violence as inextricably bound to counter-violence.

For instance in Bound to Violence, it is a force used only by exploiters against the exploited. In this bourgeoisie presentation of violence, working people did not come up even with a spontaneous response.

A critical look at the philosophical standing of Festus Iyayi, critically, on Violence, the following points are deduced: Violence is a historical phenomenon. It has a class basis. Surplus value is forcibly extracted and expropriated from the working people by the owners of the means of production. As a result, Idemudia feels that violence "...consisted not of physical brutal assault, but a slow and gradual debasement of himself, his pride as a man", (P. 243). Despite the constant presence of class violence pitted against the working people, the latter are portrayed as determined to overcome it. At work, in hospitals and at home, the working people face violence of one form or another with courage and resistance.

The novel considered religion and history as the handiwork of man entirely. His philosophical emphasis is on human labour. Man became what we know of him today as a result of labour. This is all the more reason why working people must be given their rightful place in human history. Iyayi's presentation of the truck-pushers is a good illustration of his materialistic conception of history. These two truck-pushers according to the novel did not think of the church. Their truck was their church and their labour was their God. 
Their breathing came out in small harsh strangulated gasps. Still they pushed and the trucks went up with them slowly like the shells of tortoises, ambling. These too did not think of the church. Their truck was their church and their labour was their God. (P. 221).

The author in Violence unlike other authors such as Yambo Quologuem in Le Devoir de Violence, does not give credence to any metaphysical school of thought which posit that the destiny of man is in the hands of an extra-terrestrial being. He asserts, for example, that the two children of a beggar stretching out their hands at the door step of a church '... were the children of the world, not created by God' (P. 222).

\section{Conclusion}

Finally, Festus Iyayi's concept of art agress with that of Fanon. In his novel, Violence, he sees the working class as people always in the process of asserting their existence through struggling for survival by selling their labour. They confront the future with determination. At the same time, a balanced view is given of the members of the neo-colonial comprador class. They are also portrayed as human beings; but as human beings debasing themselves and others in their efforts to appropriate the surplus -value created by the working people. Generally, in my opinion, Iyayi's concept and view of art is progressive and Fanonist because he recognizes that “... art needs a new self - consciousness." (Trotsky, 1974: 15).

\section{References}

Brecht, B. (1976). Poems 1913-1956. New York: Methuen.

Fanon, F. (1963). The Wretched of the Earth. Middle sex: Penguin Books Ltd.

Iyayi, F. (1979). Violence. Lagos. Longman Nigeria Plc.

Ouologuem, Y. (1968). Bound to Violence. London Heinemann Ld.

Trotsky, L. (1974). Literature and Revolution._New York: Monthly Review Press.

Woddis, J. (1972). Theories of Revolution. New York: International Publishers. 